\title{
Profile of victims of accidents with biological material in a course of Dentistry
}

\author{
Perfil das vítimas de acidentes com material biológico \\ em um curso de Odontologia
}

\author{
Fernanda Midori TSUZUKI' ${ }^{1}$ iD 0000-0001-8880-8036 \\ Bruna Angélica de Souza VIANA ${ }^{1}$ iD 0000-0002-0689-2834 \\ Amanda Penha MATHIAS ${ }^{1}$ iD 0000-0002-6159-5680 \\ Marcos Sérgio ENDO' ${ }^{1}$ iD 0000-0002-8980-3779 \\ Mitsue FUJIMAKI ${ }^{1}$ iD 0000-0002-7824-3868 \\ Najara Barbosa da ROCHA ${ }^{1}$ iD 0000-0003-3366-0032
}

\section{ABSTRACT}

Objective: To identify the epidemiological profile of accidents with biological material occurring in the dental clinic of a university in the southern region of the country. Methods: This is a descriptive, cross-sectional, retrospective study, which analyzed the reports of the Epidemiological Surveillance (SINAN) that occurred between March 2013 and December 2016. We analyzed the demographic variables and data related to the notification of accidents with biological material in the SINAN file, such as: age, sex, race, occupation (student, teacher, oral health technician, residents), time and place of occurrence of the accident, agent causing the perforation, total or partial use of PPE (personal protective equipment) at the time of accident, contact with organic material, contact agent and up-todate vaccination against hepatitis B and treatment withdrawal. The data obtained were analyzed in Epilnfo Software. Statistical analysis included descriptive and inferential analysis, with significance level of $\mathrm{p} \leq 0.05$ and confidence interval $(\mathrm{CI})$ of $95 \%$. Results: $\mathrm{In}$ total there were 55 reports of accidents with piercing-cutting materials, of which 12 were men (21.82\%) and 43 were women (78.18\%). The mean age of the sample population was $24.2( \pm 6.3)$ years. Regarding the occupation, $80 \%(n=44)$ were undergraduate students, $12.72 \%$ were residents, $5.45 \%$, teachers and $1.82 \%$, oral health technicians. The majority $(61.8 \%)$ were perforated during the dental procedure, $21.82 \%$ during material washing and $16.36 \%$ during surgery, but $20 \%$ claimed that they did not use any personal protective equipment. Regarding the organic material, there was a high prevalence of contact with blood, 70.9\%, the needle was the main agent $(n=26 ; 47.3 \%)$. Still, $3.7 \%$ stated that they were not vaccinated against hepatitis $B$. In the bivariate analysis, the site of the accident was associated with the use of personal protective equipment $(p=0.01)$. Conclusion: The results showed that the number of incidents is high and can be attributed to several factors, such as lack of experience of students and the non-use of personal protective equipment. As a result, it is necessary to establish a permanent education program focused on education and accident prevention strategies to minimize these problems.

Indexing terms: Containment of biohazards. Dentistry. Infection control, dental.

$\operatorname{urv}$

1 Universidade Estadual de Maringá, Departamento de Odontologia. Rua Mandacaru, 1550, Centro, 87080-000, Maringá, PR, Brasil. Correspondência para / Correspondence to: NB ROCHA. E-mail: <najara.rocha@gmail.com>.

$\boldsymbol{v} \boldsymbol{v}$

How to cite this article

Tsuzuki FM, Viana BAS, Mathias AP, Endo MS, Fujimaki M, Rocha NB. I. Profile of victims of accidents with biological material in a course of Dentistry. RGO, Rev Gaúch Odontol. 2019;67: e20190023. http://dx.doi.org/10.1590/1981-86372019000233447 


\section{RESUMO}

Objetivo: Identificar o perfil epidemiológico dos acidentes com material biológico ocorridos na clínica odontológica de uma universidade na região sul do país. Métodos: Foi realizado um estudo descritivo, transversal, retrospectivo, analisando as notificações da Vigilância Epidemiológica (SINAN) ocorridas entre março de 2013 a dezembro de 2016. Foram analisadas as variáveis demográficas e os dados referentes a notificação de acidentes com material biológico contidas na ficha do SINAN, tais como: idade, sexo, raça, ocupação (estudante, professor, técnico em saúde bucal, residentes), momento e local da ocorrência do acidente, agente causador da perfuração, uso total ou parcial de EPI no momento do acidente, contato com material orgânico, agente do contato e vacinação em dia contra hepatite $B$ e abandono do tratamento. Os dados obtidos foram analisados pelo Software Epilnfo. A análise estatística incluiu a análise descritiva e inferencial, com nível de significância de $p \leq 0,05$ e intervalo de confiança (IC) de 95\%. Resultados: No total houve 55 notificações de acidentes com materiais pérfuro-cortantes, sendo doze homens (21,82\%) e 43 mulheres (78, 18\%). A idade média da população amostral era de 24,2 ( $\pm 6,3)$ anos. Quanto à ocupação, $80 \%$ ( $n=44)$ eram estudantes de graduação, 12,72\% residentes, 5,45\% professores e 1,82\% técnico em saúde bucal. A maioria (61,8\%) se perfurou durante o procedimento odontológico, $21,82 \%$ durante a lavagem dos materiais e 16,36\% durante uma cirurgia, porém $20 \%$ alegaram que não utilizavam o equipamento de proteção individual. Em relação ao material orgânico, houve grande prevalência do contato com o sangue 70,9\%, sendo a agulha o principal agente $(n=26 ; 47,3 \%)$. Ainda, 3,7\% afirmaram não estavam vacinados contra hepatite B. Na análise bivariada, o local do acidente esteve associado com o uso do equipamento de proteção individual $(p=0,01)$. Conclusão: Os resultados mostraram que o número de incidentes é elevado e podem ser atribuídos a diversos fatores, como a falta de experiência dos estudantes e a não utilização de equipamentos de proteção individual. Em decorrência disso, é necessário estabelecer um programa de educação permanente focado em estratégias de educação e prevenção de acidentes para minimizar esses agravos.

Termos de indexação: Contenção de riscos biológicos. Odontologia. Controle de infecções dentárias.

\section{INTRODUCTION}

Biosafety is defined as: "a safety condition achieved by a set of actions aimed at preventing, controlling and reducing or eliminating risks inherent in activities that could compromise human, animal and plant health and the environment" [1]. Adherence to biosafety standards in health work is a fundamental condition for the safety of workers [2].

In dentistry, a great number of occupational risks are observed, such as biological, physical, chemical, ergonomic or accident risks, among others [1]. This demonstrates the importance of understanding the profile of accidents with biological materials that occur within a dental clinic, since this information will allow the creation of preventive strategies and behaviors to be taken after the accident, based on Regulatory Standard 32 in Work Safety in Health Facilities (NR32), approved in 2005 and developed to constitute the basic guidelines for the implementation of specific protective measures for workers [3].

Accidental exposure to piercing-cutting instruments are the most common workplace accidents involving professionals and students in a hospital setting. The risk of an injured person acquiring an infection through these exposures depends on several factors, such as: extension of the lesion, volume of biological fluid present, systemic conditions of the professional, characteristics of the microorganisms present and clinical conditions of the source patient, as well as the conducts performed after exposure. More than 20 different pathogens can be transmitted by accidental exposure [4], including hepatitis B virus (HBV), hepatitis $C$ and human immunodeficiency virus (HIV), which are the most relevant infectious agents due to the seriousness of the respective diseases. In relation to hepatitis $\mathrm{C}$ virus (HCV), the risk of occupational transmission is approximately $1.8 \%$ (ranging from 0 to 7\%) after a percutaneous accident with a positive HCV source patient [5].

The Ministry of Health certifies that Universal Precautionary measures represent a set of infection control care to be universally adopted as an effective way of reducing risk. These should be used in the care of all the patients, since not all the carriers of these pathogenic microorganisms can be identified previously. ANVISA recommends some precautions to reduce the exposure of dental professionals to biological material, such as the use of PPE, handwashing, care with piercing-cutting materials, transportation of waste and materials with caution, immunization, among others [1].

In Brazil, although work accidents due to piercingcutting materials are frequent, there is still no real diagnosis of the number of workers affected by these injuries. It is believed that the existing number is underestimated given the likely existence of underreporting among health professionals due to the lack of awareness of risk by hospital workers and managers, the fear of unemployment or loss of employment by the worker, the culpability felt in 
relation to this event, the lack of adequate organization of the actions of the service of assistance to the worker, the difficulties of the information system and also to the disbelief of the importance of the work accident of this nature [6].

Biosafety is not only about prevention and control, it is necessary to invest in a proper education for a better understanding and execution of its objectives. It is necessary to establish procedures for immediate interventions to raise awareness, with the risk of exposure to biological material intrinsic to the category of students, and to consolidate their execution, from graduation to professional life [7]. The refinements of education strategies are essential for better compliance with biosafety protocols [8]. Therefore, the goal of this study was to identify the epidemiological profile of accidents with biological materials occurred in the dental clinic of a university in the southern region of the country.

\section{METHODS}

This was a descriptive, cross-sectional, retrospective study on accidents with piercing-cutting material, which occurred in the dental clinic of a university in the southern region of the country.

Data collection was carried out by a single researcher, with consultation to the records of notifications of accidents with biological material (SINAN), in the institution between 2013 and 2016. All the SINAN files about piercing-cutting accidents of Epidemiological Surveillance Nucleus (NVE) of the University Hospital of Maringá (HU) referring to the Department of Dentistry, were analyzed.

We analyzed the demographic variables and the data related to the notification of accidents included in SINAN file, such as: age, sex, race, occupation (student, teacher, oral health technician, residents), time and place of occurrence of the accident, agent causing the perforation, total or partial use of PPE at the time of the accident, contact with organic material, contact agent and up-to-date vaccination against hepatitis $B$ and treatment withdrawal.

It was not necessary the approval by the Research Ethics Committee of the institution, because it is a research involving only data in the public domain, that is, the information provided to any citizen of the hospital surveillance and that does not identify the participants of the research.

Data were analyzed in Epilnfo Software. Statistical analysis included descriptive and inferential analysis, with application of the Fisher test, significance of $p \leq 0.05,95 \%$ confidence interval $(\mathrm{Cl})$ by the Bioestat software.

\section{RESULTS}

During this period, 55 accidents with piercingcutting materials were reported in the COD-EMU. No files were excluded. The mean age of the sample was 24.2 ( \pm 6.3) years, and the majority were young (18 to 25 years old), female (76.4\%), as listed in table 1.

Table 1. Numerical and percentage distribution of victims of piercing-cutting accidents, according to demographic data.

\begin{tabular}{lcc}
\hline Age group & $\mathrm{n}$ & $\%$ \\
\hline 18 to 25 years & 44 & 80 \\
26 to 30 years & 6 & 10.09 \\
31 to 40 years & 1 & 1.8 \\
Over 40 years & 3 & 5.4 \\
Not informed & 1 & 1.8 \\
Total & 54 & 100 \\
\hline Sex & $\mathrm{n}$ & $\%$ \\
\hline Male & 12 & 21.82 \\
Female & 43 & 78.18 \\
\hline Total & 55 & 100 \\
\hline
\end{tabular}

Among students, teachers, residents and auxiliaries, the category with the highest number of notifications were undergraduate students $(80 \%)$, followed by residents $(12.72 \%)$, teachers $(5.45 \%)$ and oral health technicians (1, $82 \%)$ during the analyzed years.

During the accident, $80 \%$ of victims reported using all PPE relevant to dental care. The other 11 reports indicate that $20 \%$ had used PPE, however incomplete, without gloves, glasses or aprons. Within these reports, (n =3) were without gloves.

The majority of accidents (62\%) occurred during the dental procedure, $21.8 \%$ during the washing of the materials and $16.4 \%$ during the surgical procedure. There 
were also accidents during needle recapping and suture (3.6\%).

Of the 12 victims who were perforated during material washing, half neglected to use PPE (table 2).

Table 2. Association between the use of PPE and variables.

\begin{tabular}{llccc}
\hline \multirow{2}{*}{ Variables } & \multicolumn{2}{c}{ Use of complete PPE } & \\
\cline { 3 - 4 } & Mes n (\%) & No n (\%) & $\mathrm{p}$ \\
\hline \multirow{2}{*}{ Time of accident } & $\begin{array}{l}\text { Material washing } \\
\text { Dental / Surgical }\end{array}$ & 6 & 38 & \\
& $\begin{array}{l}\text { Procedure } \\
\text { Type of fluid }\end{array}$ & 6 & 6 & 0.01 \\
& $\begin{array}{l}\text { Blood } \\
\text { Other materials }\end{array}$ & 30 & 9 & \\
\hline
\end{tabular}

Perforation with needle (47.3\%) represented the majority of piercing-cutting accidents, followed by cut with blades (7.27\%) and exploratory probes (3.6\%). Files, drills, curettes and steel matrix represent $1.8 \%$ each (table 3 ). Most of the victims had contact with the patient's blood $(70.9 \%)$ in the occurrences; contact with saliva represented a little more than $12 \%$; carious tissue only $1.82 \%$ and other fluids $14.56 \%$ (table 3 ).

Table 3. Numerical and percentage distribution of accidents with piercing-cutting accidents of COD-UEM.

\begin{tabular}{lcc}
\hline Type of exposure & $\mathrm{n}$ & $\%$ \\
\hline Needle with or without lumen & 26 & 47.3 \\
Blades & 4 & 7.27 \\
Exploratory probe & 2 & 3.6 \\
File & 1 & 1.8 \\
Drills & 1 & 1.8 \\
Curettes & 1 & 1.8 \\
Steel matrix & 1 & 1.8 \\
Other materials & 19 & 34.54 \\
Total & 55 & 100 \\
\hline Biological material involved & $\mathrm{n}$ & $\%$ \\
\hline Blood & 39 & 70.9 \\
Saliva & 7 & 12.7 \\
Carious tissue & 1 & 1.82 \\
Other fluids & 8 & 14.56 \\
\hline Total & 55 & 100 \\
\hline
\end{tabular}

In the first year of analysis, 2013, thirteen occurrences (23.64\%) were reported; this number decreased to twelve notifications $(21.82 \%$ ) in 2014 , ten notifications (18.18\%) in 2015 and double notifications occurred in 2016 (table 4).

Table 4. Numerical and percentage distribution of victims of piercing-cutting accidents, according to the year of occurrence.

\begin{tabular}{lcc}
\hline Year of accident & $\mathrm{n}$ & $\%$ \\
\hline 2013 & 13 & 23.64 \\
2014 & 12 & 21.82 \\
2015 & 10 & 18.18 \\
2016 & 20 & 36.36 \\
\hline Total & 55 & 100 \\
\hline
\end{tabular}

Some students stated that they did not have hepatitis vaccination (3.7\%), and more than $9 \%$ did not know whether they had up-to-date vaccination.

Regarding the abandonment of treatment, in 2013 and 2014 there is no record of information. From 2015 onwards, it was reported that the dropout rate was quite high (figure 1).

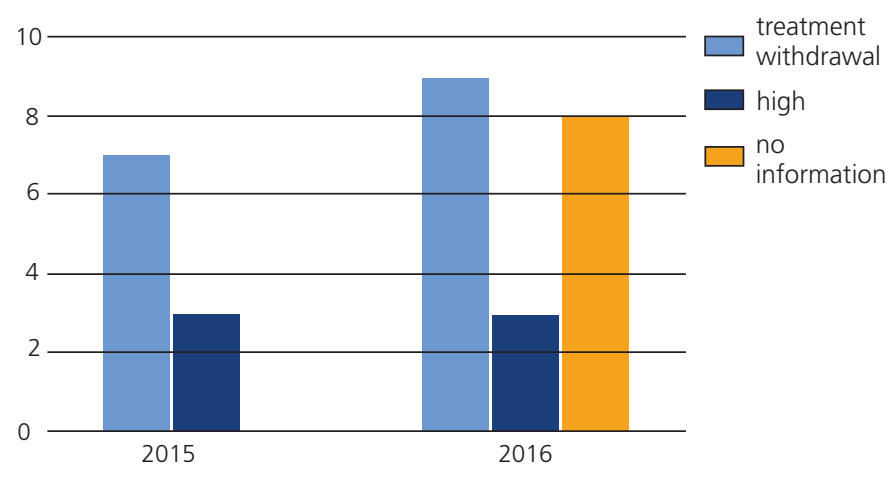

Figure 1. Numerical and percentage distribution of the treatment withdrawal rate, according to the year of occurrence.

\section{DISCUSSION}

The data showed the profile of accidents with biological materials in health workers. The files analyzed show a high number of women who have suffered from an accident. The prevalence of female sex $(76.4 \%)$ was observed in other studies in the literature [9-11], which can be attributed to the greater number of women in the 
health area and within the dental team. Orestes Cardoso et al. [11] showed that among the professionals of the dental team $70.3 \%$ are women.

The health professionals of this study who suffered the highest number of accidents and who reported were the students, that is, $80 \%$ of the injured. Students are more frequently injured because they participate in various procedures and are often associated with scarce knowledge about universal precautionary measures and repeated training under appropriate supervision, as well as nervousness and/or inexperience during procedures $[12,13]$.

Due to the particularities of dental procedures, which are performed in a small space for the manipulation of the instruments by the dental surgeon, the access inside the mouth becomes difficult. In addition to being common and necessary the handling of long, piercing-cutting instruments, such as curettes, explorers, needles, forceps, drills, files, among others, which remain in intense contact with blood, saliva, and other biological materials that impregnate the materials, the reduced space also increases the risk of occupational accidents [14]. This may be the justification for a large number of accidents (62\%) during the dental procedure and also during surgical procedures (16.4\%).

Needle perforation (47.3\%) represented the majority of piercing-cutting accidents, as well as data reported by the São Paulo State Department of Health, which presents among the records of accidents involving dental procedures (representing $7.1 \%$ notifications), hypodermic and gingival needles as the instruments that caused the greatest number of accidents (63\%). The results showed important failures in the follow-up of the pre-established protocol and in the care flow chart [14].

There was a high occurrence of victims who had contact with the patient's blood (70.9\%). According to data from the Ministry of Health, after percutaneous occupational exposure to contaminated blood the risk of HIV infection approaches $0.3 \%$ and, after mucosal exposure, increases to approximately $0.09 \%$ [15]. As for occupational exposure to hepatitis B virus (HBV), the risk of infection ranges from $6 \%$ to $30 \%$ and, according to the condition of the source patient, can reach up to $40 \%$ [16].

From 2007 to June 2015, 136,945 cases of HIV infection were reported in SINAN, in Brazil [17]. The cases of HIV infection among health workers in the world, according to the data available in September 1997, comprised 264 cases [18]. The low number of seroconversions in Brazil shows a lack of effective surveillance and an inefficient reporting system for this type of accident, in addition to the low systematic monitoring of the affected professionals [19].

The treatment abandonment rate of the professionals who initially sought assistance and reported their accidents, causes great concern. A survey carried out in a public teaching hospital in São Paulo [20] showed a 45\% dropout rate in 326 reported accidents; while in a public teaching hospital in Porto Alegre, the rate was 36\% in 241 reported accidents [21]. In the study, it was noted the importance of registering patients who continued and abandoned treatment, since the records only started to be made from 2015 and in 2016, and many of the records found did not present complete information regarding the treatment.

In terms of exposure to the HBV virus, this risk can be reduced by immunization against hepatitis $B$. In a previous study, the effectiveness of the vaccine was around $90-95 \%$ and is one of the main measures to prevent the virus [19]. In the present study, a worrying number of students stated that they did not have vaccination against hepatitis $(3.7 \%)$. Therefore, serological tests for confirmation of immunization are necessary, since about $10 \%$ to $20 \%$ of the vaccinated individuals do not reach the protective levels of antibodies [22].

Ministry of Health Ordinance 597 of 2004 makes compulsory vaccination for enrollment in universities throughout Brazil [23]. However, a study published in 2006 states that higher education institutions should pay more attention to immunization because the approach to the subject has been fragmented and insufficient for the student to construct sufficient knowledge for practical application [24].

During the accident, $80 \%$ victims reported using all PPE relevant to dental care. In a study with students from the State University of São Paulo, only $19.7 \%$ of the interviewees considered the lack or misuse of the PPEs as a contributing factor to their accident with biological material [25]. Important data when compared to a study by Machado Carvalhais et al. [26], which shows that the lack or misuse of PPEs generates a greater number of occupational accidents.

The evaluation period of the records was selected, since the notifications began to be made by the 
Epidemiological Surveillance Nucleus (NVE) of the University Hospital (HU) of UEM only from 2013, before this period there was no control of the accidents. Most occurrences were recorded in 2016 (20 cases, 36.36\%). Two actions that justify this increase in the number of cases were intensified this year. The first one was the improvement of the flowchart for the treatment of piercing-cutting accidents, and the other was that during that year there was a greater concern with the notifications and lectures were given stimulating biosafety, strategies for accident prevention and flow for post-accident care.

The procedures presented at the clinic for improvement in the flowchart were recommended by the Ministry of Health and involved: interrupting care, removing the glove and locating the lesion; immediately wash the lesion with running water and soap; asking the patient if he/she is a carrier of HIV/AIDS, hepatitis B/C or another sexually transmitted disease and if he/she is an intravenous drug user; asking the patient if he/she agrees to provide a blood sample to test the presence of bloodborne pathogens; seek medical attention - assessment of the type of biological material involved, the severity and type of exposure, identification or not of the source-patient and its anti-HIV and anti-HBV serological condition [1].

The concern with the notifications is due to the fact that the number of occupational accidents in Brazil involving biological material is similar to those observed in other countries when the incidence of accidents and underreports is compared. A study evaluating underreporting in a university hospital in São Paulo shows that from $41 \%$ to $49 \%$ are underreporting of accidents. The allegations mentioned by the professionals for non-notification of the accident were based on lack of knowledge about the risks and/or no need for notification [27]. Therefore, the number of notifications could be much greater and therefore the importance of prevention and continuing education to promote the importance of reporting and prevention of piercingcutting accidents.

Another contribution to the increase in the number of notifications in the 2016 data of the research was the availability of lectures stimulating work safety, the use of PPE, preventive methods to avoid piercing-cutting accidents and the vaccination control of students of all grades prior to the start of the clinic in addition to immunization testing for evidence. It is known that for the success of accident prevention, constant guidance is required, so that knowledge is translated into practice, as an important gain to the health of the professionals involved.

This was the first study of this type performed at the dental clinic of the State University of Maringá (UEM). These results may have important implications for health care, not only for the clinical benefit of the patient and the professional, but also for the reduction of hospital costs with examinations and collection time. It is necessary to strengthen prophylactic measures with the aim of minimizing such incidents harmful to the health of those involved, whether patient, teachers, students or employees. However, the survey was the first step in improving protection measures. It will be necessary to follow the permanent education process in place to better evaluate whether there will be a reduction in the number of contamination and accidents, a decrease in the number of underreporting and the processes that occur due to negligence of the important safety procedures at work.

Some limitations of the study should be considered. The first is for being a cross-sectional study, longitudinal studies need to be carried out following these accidents to verify causal relationships and perceptions of accident victims. The other would be incomplete completion of the data made by those responsible for the notification, a fact also reported by other authors [4]; this impairs the quality and relevance of the information and the exact definition of the problem dimension.

\section{CONCLUSION}

The results show that the number of incidents is high and can be attributed to a number of factors, such as lack of experience of students and non-use of personal protective equipment. As a result, it is necessary to establish a permanent education program focused on education and accident prevention strategies to minimize these problems.

\section{Collaborators}

FM TSUZUKI, significant participation in study design, data collection, data analysis / interpretation; and during the drafting and revision of the manuscript. BAS VIANA, involvement in data collection, analysis / interpretation of data; and during 
the writing of the manuscript. AP Mathias, involvement in data collection, data analysis / interpretation; and during the writing of the manuscript. MS ENDO, involvement in drafting and revising the manuscript. M FUJIMAKI, involvement in drafting and revising the manuscript. NB ROCHA, significant participation in the design of the study, such as research group leadership, statistical analysis and revision of the manuscript.

\section{REFERENCES}

1. Brasil. Ministério da Saúde. Agência Nacional de Vigilância Sanitária. Serviços odontológicos: prevenção e controle de riscos. Brasília: Ministério da Saúde; 2006 [citado 2018 Nov]. Disponível em: <http://www.anvisa.gov.br/servicosaude/ manuais/manual_odonto.pdf>.

2. Gir E, Takahashi RF, Oliveira MAC, Nichiata LYI, Ciosak SI. Biossegurança em DST/AIDS: condicionantes da adesão do trabalhador de enfermagem. Rev Esc Enferm USP. 2004;38(3):245-53. http://dx.doi.org/10.1590/S0080-62342004 000300002

3. São Paulo (Estado). Secretaria de Estado da Saúde. Normas regulamentadoras $n^{\circ} 7, n^{\circ} 9$ e $n^{\circ} 32$. São Paulo: Editora; 2014 [citado 2018 Nov]. Disponível em: <http://www. saude.sp.gov.br/resources/crh/ggp/cartilhas/normas_ regulamentares.pdf>.

4. Brozoski MA, Traina AA, Naclério-Homem MG, Deboni MCZ. Ocorrência de acidentes pérfuro-cortantes em um curso de odontologia. RGO, Rev Gaúcha Odontol. 2010;58(1):77-80.

5. Brasil. Ministério da Saúde. Recomendações para o atendimento e acompanhamento de exposição ocupacional a material biológico: HIV e Hepatites B e C. Brasília: Ministério da Saúde; 2004.

6. Marziali MHP, Rodrigues CM. A produção científica sobre os acidentes de trabalho com material perfurocortante entre trabalhadores de enfermagem. Rev Latino-Am Enferm. 2002;10(4):571-7. http://dx.doi.org/10.1590/S0104-11692002 000400015

7. Bonis MD, Costa MAF. Educação em biossegurança e bioética: articulação necessária em biotecnologia. Ciênc Saúde Coletiva. 2009;14(6):2107-14. http://dx.doi.org/10.1590/S1413-81 232009000600017

8. Pinelli C, Garcia PPNS, Campos JÁDB, Dotta EAV, Rabello AP. Biossegurança e odontologia: crenças e atitudes de graduandos sobre o controle da infecção cruzada. Saude Soc. 2011;20(2):448-61. http://dx.doi.org/10.1590/S0104-1290 2011000200016

9. Barreira THC, Filho JMJ. Effectiveness in the implementation of policies in the Occuptional Safety and Health $(\mathrm{OSH})$ field and new forms of action. Rev Bras Saúde Ocup. 2009; 34(119):4-5.

10. Vieira M, Padilha MI, Pinheiro RDC. Análise dos acidentes com material biológico em trabalhadores da saúde. Rev Latino-Am Enferm. 2011;19(2):[08 telas].
11. Orestes-Cardoso SM, Farias AB, Pereira MRMG, OrestesCardoso AJ, Cunha JIF. Acidentes perfurocortantes: prevalência e medidas profiláticas em alunos de odontologia. Rev Bras Saúde Ocup. 2009;34(119):6-14. http://dx.doi.org/10. 1590/S0303-76572009000100002

12. Panagakos FS, Silverstein J. Incidence of percutaneous injuries at a dental school: a 4-year retrospective study. Am J Infect Control. 1997;25(4):330-4. https://doi.org/10.1016/S0196-65 53(97)90025-0

13. Ribeiro PHV. Acidentes com material biológico potencialmente contaminado em alunos de um curso de odontologia do interior do estado do Paraná [dissertação]. Ribeirão Preto: Universidade de São Paulo; 2005.

14. Graziano KU, Graziano RW. Limpeza, desinfecção e esterilização de artigos odontológicos e cuidados com o ambiente. In: Associação Paulista de Estudos e Controle de Infecção Hospitalar (APECIH). Controle de infecção na prática odontológica. São Paulo: APECIH; 2000. p. 11-24.

15. Centers for Disease Control and Prevention. Public health service guidelines for the management of health-care worker exposures to HIV and recommendation for post exposure prophylaxis. MMWR. 1998; 47(RR-7): 1-33.

16. Brasil. Ministério da Saúde. Secretaria de Políticas de Saúde, Coordenação Nacional de DST e AIDS. Manual de condutas: exposição ocupacional a material biológico: hepatite e HIV. Brasília: Ministério da Saúde; 1999 [citado 2018 Nov]. Disponível em: <http://bvsms.saude.gov.br/bvs/ publicacoes/04manual_acidentes.pdf>.

17. Brasil. Ministério da Saúde. Secretaria de Vigilância em Saúde. Boletim epidemiológico - Aids e DST. Brasília: Ministério da Saúde; 2016 [citado 2018 Nov]. Disponível em: <http://www. aids.gov.br/pt-br/pub/2016/boletim-epidemiologico-deaids-2016>

18. Ippolito G, Puro V, Heptonstall J, Jagger J, De Carli G, Petrosillo N. Occupational Human Immunodeficiency Virus: worldwide cases through September 1997. Clin Infect Dis. 1999;28:365-83.

19. Gir E, Netto JC, Malaguti SE, Canini SRMS, Hayashida M, Machado AA. Accidents with biological material and immunization against hepatitis $B$ among students from the health area. Rev Latino-Am Enferm. 2008;16(3):401-6.

20. Brasil. Ministério da Saúde. Secretaria de Vigilância em Saúde. Exposição a materiais biológicos. Brasília: Ministério da Saúde; 2009 [citado 2018 Nov]. Disponível em: <http://bvsms.saude. gov.br/bvs/publicacoes/protocolo_expos_mat_biologicos. pdf>.

21. Carvalho VG, Maciel DN, Hoefel MG, Yates ZB, Viana MC, Trindade DM. Perfil de aderência ao controle/seguimento após acidente com material biológico em um hospital universitário.

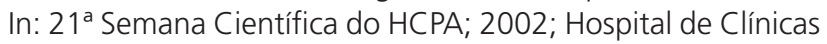
de Porto Alegre. Porto Alegre: Revista HCPA; 2002. p. 254.

22. U.S. Public Health Service. Updated U.S. Public Health Service guidelines for the management of occupational exposures to HBV, HCV and HIV and recommendations for postexposure prophylaxis. MMWR Recomm Rep. 2001;50(RR-11):1-52.

23. Brasil. Ministério da Saúde. Portaria n. 597/GM, de 8 de abril de 2004. Institui, em todo território nacional, os calendários 
de vacinação. Diário Oficial da União, Brasília (DF); 2004 abr 12; Seção 1:69.

24. Santos SLV, Souza ACS, Tipple AFV, Souza JT. O papel das instituições de ensino superior na prevenção das doenças imunopreveníveis. Rev. Eletrônica Enferm. 2006;8(1):91-6.

25. Canalli RTC, Moriya TM, Hayashida M. Prevenção de acidentes com material biológico entre estudantes de enfermagem. Rev. enferm. UERJ. 2011;19(1):100-6.

26. Machado-Carvalhais HP, Ramos-Jorge ML, Auad SM, Martins LH, Paiva SM, Pordeus IA. Occupational exposure to potentially infectious biological material in a dental teaching environment. J Dent Educ. 2008;72(10):1201-8.

27. Destra AS, Sassi SJG, Bachega CIF, Coutinho AP, Medeiros EAS. Avaliação da subnotificação de acidentes profissionais com material biológico (MB) em um hospital universitário - Fase III. In: Anais do VIII Congresso Brasileiro de Controle de Infecção e Epidemiologia Hospitalar; 2002; Curitiba.

Received on: 12/6/2018 Final version resubmitted on: 20/10/2018 Approved on: 5/12/2018 